\title{
The Role of Craft and Artisan Cooperative Societies in the Socio-Economic Advancement of Its Members in Abia State, Nigeria
}

\author{
Udensi, Lawrence Okoronkwo \\ Youth Empowerment and Child Labour Elimination Project (YCEP) Calabar, Cross River State, Nigeria \\ E-mail: Ludensi@ymail.com Tel: +234 8063988141 \\ Igbara, Felix N \\ Department of Banking and Finance Rivers State Polytechnic Bori Rivers State, Nigeria \\ Paago, Johnny $k$ \\ Department of Banking and Finance Rivers State Polytechnic Bori Rivers State, Nigeria \\ Chieke, Esther Onyinyechi
}

M.Sc. student, department of sociology, university of Calabar, Calabar, Cross River State, Nigeria

\section{Doi:10.5901/mjss.2014.v5n2p483}

\section{Abstract}

This study has been undertaken with the purpose of assessing the role of craft and artisan cooperatives in the socio-economic advancement of their members in Abia State. The paper specifically identify and describes the socio-economic characteristics of members of the cooperative societies; find out the ways that members benefit from the cooperative group; examine the contributions of the cooperatives to rural economic activities in the study area; identify the constraints limiting the optimum performance of the cooperatives in the study area and make recommendations for greater effectiveness of craft and artisan cooperative societies in the study area. Survey design was adopted to conduct this study. Data was collected with the help of a self-administered researcher-constructed Questionnaire administered on 400 members of craft and artisan cooperative societies that were purposively selected. A pilot test of the instruments gave reliability estimates of 0.79 . Data was analyzed descriptively using frequency, simple percentage and rank-order respectively. Results obtained (partial listing) indicated that education (of members) is a significant indicator that can effectively mobilize cooperative societies to attract government presence for assistance, lack of educated members could hinder the leadership structure of the group. Meeting frequently (usually weekly) could help to sustain cooperative societies and also serve as a catalyze for sharing of knowledge and new ideas which could be effective in improving business, solving personal and group challenges as well as increase work productivity. The Osusu scheme could help to abate poverty and solve the problem of insufficient and lack of fund which a significant population of craft men and artisans face often times. Finally, result shows that insufficient fund, migration, non governmental support, corruption among leaders etc. are some of the limiting factors to the optimum performance of craft and artisan cooperative societies in the study area. It was therefore concluded that organize effort to mobilize craft and artisans for cooperative spirit in the study area, and anywhere else, could assist to increase access to fund, dissemination of information and innovations, and reduce poverty.

Keyword: Role; craft and artisans; cooperative societies; socio-economic; advancement; rural economy

\section{Introduction}

The context of interest for this study is Cooperative Society and there have been several definitions outlined within this context. International Co-operation Alliance (ICA) (1995) defines Cooperative Society as an autonomous association of persons united voluntary to meet their common economic, social and cultural needs democratically controlled enterprise. Also, Ebonyi and Jimo (2002) on their part described cooperative societies as associations of persons who have voluntarily come together to achieve common objectives through the formation of democratically controlled organization; making equitable contributions to the capital required and accepting a fair share of the risk and benefits of the undertakings. UWCC, (2002) summarily describes Cooperative Society as a business or group enterprise that is 
voluntarily owned and controlled by its members, patron and operated for them on a non-profit or cost basis. This definitions clearly points out the essence of collective behavior with it expectations which necessitate the present study. The essence of this cooperation as observed by Dogarawa (2005) is an effective way for people to exert control over their livelihoods; provide a unique tool for achieving one or more economic goals in an increasingly competitive global economy; own what might be difficult for individuals to own or pursue by their efforts; strengthen the communities in which they operate through job provision, generally, cooperative provide an economic boost to the community. This cooperation to Audu et al. (2007) enables people to achieve through joint efforts, what they are unable to achieve while working as individual.

Unavailability of funds to rural dwellers has been consistently reported in extant literatures and researches to be a hindrance to rural productive ventures (Ekong 2007; Aremu, 2004; Ndifon, 2012). Cooperative societies therefore have the enormous potentials to address these issues. Audu et al. (2002) elucidated that group efforts are necessary to bring people together so that they can use pooled resources to produce. Cooperative societies are therefore veritable instruments to use in achieving this goal. The ILO report in 2001 and Mukarugwiza (2010), characterized cooperative societies as having the potentials for economic, social and political development of their members. According to the ILO (2001), the economic role of cooperative involves provision of opportunities for improved incomes to members as well as tool to help alleviate poverty. Cooperatives play an important role in facilitating access to credit, procurement and storage distribution of input and marketing of products, these create employment opportunities particularly in the rural areas and allow disadvantaged groups to be organized for social and economic benefit.

According to Brawerman et al., (1991); Gertler, (2001); Dogarawa, (2005); Gibson, (2005); Berko, (2001) craft and artisans cooperatives have the ability to develop rural economy and improve the socio-economic conditions of its members. Because of this, there has been considerable expectation from these cooperatives to achieve social and economic goals and also spur development and alleviate poverty. It is against this background that various Micro and Small Scale Enterprises (MSEs) have grouped themselves for greater efficiency and effectiveness through mutual cooperation.

This study has been undertaken with the purpose of assessing the role of craft and artisan cooperatives in the socio-economic advancement of their members in Abia State. The paper specifically identify and describes the socioeconomic characteristics of the members; find out the ways that members benefit from the cooperative group; examine the contributions of the cooperatives to rural economic activities in the study area; identify the constraints limiting the optimum performance of the cooperatives in the study area and make recommendations for greater effectiveness of craft and artisan cooperative societies in the study area.

\section{Theoretical Framework}

In other to bring this paper into proper perspective, the exchange theory has been chosen to analyze the role of craft and artisan cooperative societies in the advancement of the socio-economic lives of its members. The exchange theory is founded on the ideas of George Casper Homans, Peter M. Blau, Richard Emerson and James S. Coleman. The exchange theory is built on the principle of give and take. However, the micro - macro opinion of Homans (micro) and Blau (macro) has painted a better portrait for exchange theory analysis on the importance of cooperative societies in social interaction. According to Charles (2010), the fundamental question which exchange seeks to ask is the 'quid pro quo' - something given as compensation. That is, in a situation of exchange, one has to ask "what will I gain from this interaction?" this, Charles further explained that gain or loss is quickly calculated mentally before an actor engages in any interaction. From the foregoing therefore, members of craft and artisan cooperative group are attracted to the group as a result of the gains or benefits they stand to derive as members.

The binding force to the strong commitment of members and sustenance of the cooperative group becomes possible due to the fact that reciprocity enhances exchange in the society and sustains relationship (Charles, 2010). Considering some benefit derived by members of cooperative societies [financial assistance through loan scheme and Osusu (Rotatory savings and contributory scheme), social recognition, improvement in business, emergency response etc.], the relationship (between members and the group) can be sustained if members gives back to the group through active commitment as members, prompt refunds of loan, payment of dues and donations etc.

According to Ritzer (2008), Blau and Homans were interested in similar processes. However, Blau's concept of social exchange is limited to actions that are contingent, which depends on rewarding reactions from others. According to him (Ritzer), people are attracted to each other for a variety of reasons that induce them to establish social associations. Once initial ties are forged, the rewards that they provide to each other serve to maintain and enhance the bonds. 
Cooperative societies are the product of social interaction. Micro relationships are the building block for macro relationships. This is anchored on the felt needs and agreed upon a goal (which is described as common values according to Blau, 1964). Blau's position in the words of Ritzer (2010) is similar to Homan's position. But he (Blau) expatiated his position to the level of social facts. According to him, we cannot analyze process of social interaction apart from the social structure that surrounds them. To justify the position through which social structures are formed, it is therefore imperative to note that social structures emerges from social interaction, but once this occurs, social structures have a separate existence that affects the process of interaction. The above position crystalizes the basis through which cooperative groups are formed and sustained.

\section{The Study Area}

According to Wikipedia (2013), Abia is a state in the south eastern part of Nigeria. The capital is Umuahia and the major commercial city is Aba, formerly a British colonial government outpost. The state was created in 1991 from part of Imo State and its citizens are predominantly Igbo people (95\% of population). Abia State, which occupies about 5,834 square kilometers, is bounded on the north and northeast by the states of Anambra, Enugu, and Ebonyi. To the west of Abia is Imo State, to the east and southeast are Cross River State and Akwa Ibom State, and to the south is Rivers State. The southern part of the State lies within the riverine part of Nigeria. It is low-lying tropical rain forest with some oil-palm brush. The southern portion gets heavy rainfall of about 2,400 millimeters (94 in) per year especially intense between the months of April through October. The rest of the State is moderately high plain and wooded savanna.

The most important rivers in Abia State are the Imo and Aba Rivers which flow into the Atlantic Ocean through the Niger Delta. English is widely spoken and serves as the official language in governance and business. Abia being a commercial state, the need to bring out policy recommendations that will help boast the state economy through revitalizing Small and Medium Scale Enterprises, the presence of large numbers of craft and artisans who are challenged in diverse areas such as: unavailability or poor access to fund, poor leadership, migration, lack of business management/improvement skill etc. are the basis that necessitates the present study.

\section{Methodology}

The population of this study was 400 respondents consisting of membership of craft and artisan cooperative societies residing in Abia state, Nigeria. The study adopted the survey design and employed exchange theory in describing the phenomenon. Purposive sampling technique was adopted in selecting the respondents which cuts across the three senatorial districts in Abia State. Questionnaire was the main instrument used for data collection. There were 20 items in the questionnaire rated with 4-point Likert scale (4, 3, 2,1) indicating, 4 Strongly Agree, 3 Agree, 2 Disagree and 1 Strongly Disagree respectively. The questionnaire was subjected to face and content validation. The questionnaire was also subject to reliability test (using the split-half method) and correlation coefficient was 0.79 , which was regarded as high. The questionnaire were personally administered and collected by same source. Data was analyzed descriptively using frequency, simple percentage and rank-order respectively

\section{Findings and Discussion}

\subsection{Socio-economic characteristics of members of craft and artisan cooperative societies in Abia State}

Table 1 shows the socio-economic characteristics of respondents. Data analysis in Table 1 below revealed that 24.7\% of the respondents are between the age range of $18-27$ years; $18.6 \%$ are between $28-37$ years; $27.7 \%$ are between $38-47$ years; $16.7 \%$ are between the age range of $48-57$ years while $12.3 \%$ are 58 years and above.

Table 1: Socio-economic Characteristics of members of craft and artisan cooperative societies in Abia State $(\mathrm{N}=400)$

\begin{tabular}{|c|c|c|}
\hline Characteristics & Frequency & Percentage (\%) \\
\hline Age & & \\
\hline $18-27$ & 99 & 24.7 \\
\hline $28-37$ & 74 & 18.6 \\
\hline $38-47$ & 111 & 27.7 \\
\hline $48-57$ & 67 & 16.7 \\
\hline \multicolumn{3}{|c}{} \\
& 485 \\
\hline
\end{tabular}


Source: Author's Fieldwork, 2013

\begin{tabular}{|c|c|c|}
\hline $58+$ & 49 & 12.3 \\
\hline Education & & \\
\hline No formal education & 216 & 54 \\
\hline Primary education & 85 & 21.3 \\
\hline Secondary education & 62 & 15.5 \\
\hline Post-Secondary Education & 37 & 9.2 \\
\hline Level of Income & & \\
\hline$<20,000$ & 309 & 77 \\
\hline$>20,000$ & 91 & 23 \\
\hline Duration of Residence & & \\
\hline$<10$ years & 308 & 76.8 \\
\hline$>10$ years & 92 & 23.2 \\
\hline
\end{tabular}

Data in table 1 further revealed that majority (54.0\%) of the respondents (more than half) had no formal education; $21.3 \%$ had primary education; $15.5 \%$ had secondary education while a relatively low percentage (9.2\%) of the respondents had post-secondary education. This shows that education could be a significant indicator that can effectively mobilize cooperative group to attract government presence to assist the group. This has been the reason why cooperative groups have existed in isolation to government assistance which is a hindrance to effective performance by cooperative groups. Also lack of education could greatly hinder the leadership structure of the group. Education of members could also help to organize cooperative societies for an effective and efficient managements, which could help to bring back the already loss of trust and confidence in leaders. This could be achieved through capacity building of members in areas of bookkeeping, recording, general administration of the group, as well as improved welfare packages for Members. Hereby leading to sustainability of cooperative group in the study area.

Result also show that the income level of members of the Cooperative Society is low with $77 \%$ of the members earning a monthly income of less than N20, 000 Naira while $23 \%$ earn above N20, 000 monthly. This shows a very low income earning abilities of members of the cooperative society, therefore, an organized effort directed at Rotatory Saving and Credit Association (ROSCA) as well as Fixed Saving and Credit Association (FISCA) including government assistance especially in the areas of capacity building, procurement of tools and financial grants will be of great importance.

Finally findings in Table 1 shows that migration of members has significantly affected the membership of the groups more than $76.8 \%$ of the group membership are members for less than 10 years. It therefore show that if craft and artisan cooperative societies are adequately mobilized, financed and encouraged, it will reduce the tide of rural-urban migration with its attendant negative consequences on both the rural and urban economy. From the above findings, the monthly turnover in investment and production (level of income of respondents) as reported in table 1 (socio-economic characteristics of respondents), the available income due the association is grossly meager. In this case, expectations by cooperative members are not realized and their socio-economic status is not improved as expected. Therefore if craft and artisan cooperative groups could adequately mobilize to attract and gain government support they could access sufficient fund which could help them realize a better turnover in production and investment thereby improving the local economy and also abate the tide of rural-urban migration which are collectively a great performance challenge to craft and artisan cooperative group in the study area.

\subsection{Contributions/Benefits of craft and artisan cooperative societies to its members in Abia State}

Table 2 represents the benefits members of the cooperative groups have derived. Data in Table 2 shows that within each benefit (100\% each), members of the craft and artisan cooperative group have derived benefit from the group in diverse areas varying from financial need/improvement of business (79.0\%), to assistance to acquire tools and materials for work (77.7\%), taking quick actions during emergencies (77.2\%), social recognition (57.2\%), medical assistance (46.5\%) and $30.2 \%$ of gift for family ranging from household property, cloth and food stuff usually during festive period.

Table 2: Contributions / Benefits of craft and artisan cooperative societies to their members in Abia State

\begin{tabular}{|l|c|c|}
\hline Contribution/Benefits to members & Frequency & Percentage (\%) \\
\hline Financial need/Improvement in business & 316 & 79.0 \\
\hline Procurement of tools and materials & 311 & 77.7 \\
\hline
\end{tabular}


*Multiple responses

\begin{tabular}{|l|l|l|}
\hline Emergency response & 309 & 77.2 \\
\hline Social recognition & 229 & 57.2 \\
\hline Medical assistance & 186 & 46.5 \\
\hline Gift to family & 121 & 30.2 \\
\hline
\end{tabular}

Source: Author's Fieldwork, 2013

From the above findings, it becomes clear that craft and artisans cooperative societies are a vehicle to spur development and abate poverty among Small and Medium Scale Enterprises (SMSEs). Respondents as noted in Table 3 above have greatly derived benefit especially in the area of business improvement and better repositioning of business through procurement of tool and materials which will help to spur production and mobilize resource which will not only alleviate poverty but also boast the rural economy. Also, the social recognition that members of this cooperative group derive has helped in the sustainability of cooperative movement in the study area.

Weekly meetings of the group (usually on Sundays) have provided a forum for social interaction which is essential for dissemination of information and learning among members, for instance, the spread of knowledge about health, education, politics, innovations as well as best practices for leadership of the group could be achieved from attendance in weekly meetings. This weekly meetings of the group has further necessitated the group to organize themselves for money saving and loaning scheme (Osusu) which they either operate as Rotatory saving and credit or Fixed saving and credit. Finally, such gathering and social interaction could help ease the stress of the previous week and prepare them for a fresh week's business activities. This will increase total turnover on investment and production of craft and artisans in rural economy.

\subsection{Sources of income of craft and artisan cooperative societies in Abia State}

Data in table 3 reveals sources of income of craft and artisan cooperative societies in the study area. From the date presented in table 3 below, results shows that the association generates income more from donations and levies from its members which ranked first, interest accrue from loans given to its members was another source that respondents identified as a source of revenue to the association and it ranked second; respondent also noted that the association generates revenue form fines due to late coming, absent from meetings, noise making, or any other violation (s) that is punishable by the association's constitution. However, the punishment by fines on members who violates the association's rules and regulations has assisted in ensuring discipline among members, which is also a source of social learning on morals and etiquette. Nevertheless, the finding on income generation by craft and artisan cooperative societies in the study according to Audu et al (2007) have the capacity to reflect and to respond to the needs of their members; and , at the same time, to help foster attitude of self-reliance and self-confidence within a framework of mutual aspiration and mutual action in the delivery of services to their members, they can provide an essential support to the development objective of both their members and the economy as well.

Table 3: Rank order of sources of income of craft and artisan cooperative societies in Abia State $(N=400)$

\begin{tabular}{|l|c|c|c|}
\hline \multicolumn{1}{|c|}{ Sources of Income } & Respondent & Rate of Mention (\%) & Rank \\
\hline Donations and levies from members & 168 & 42.0 & $\mathbf{1}$ \\
\hline Fines on members & 95 & 23.7 & $\mathbf{3}$ \\
\hline Interest on loans given to members & 119 & 29.8 & $\mathbf{2}$ \\
\hline External sources & 18 & 4.5 & $\mathbf{4}$ \\
\hline
\end{tabular}

Source: Field work. 2013

Table 3 shows the rank order of the sources of income of craft and artisans cooperative group in Abia State. Data in Table 3 reveals that the association's major source of income is from donations and levies from its members, this is followed by interest on loan given to its members, fines impose on members and lastly, external sources (which usually is gotten during political campaigns, project implementation grant award by NGOs - Non Governmental Organizations or former members that have gotten a better source of income) which is very low with only 4.5 percent response of respondents. However, the fact that donations, levies, interest on loans and fines as source of income to the association 
exposes the association to some amount of capital (income) which if adequately and judiciously managed or utilized could ensure greater access to finance to craft and artisans cooperative societies for greater effectiveness and performance which has been a challenge to them securing from modern banking system.

\subsection{Factor limiting the optimum performance of craft and artisan cooperative societies in Abia State}

Data in Table 4 represents limiting factors that have hundred craft and artisan cooperative groups from improving the socio-economic status of their members in the study area.

Table 4: Respondent's responses on factor limiting the optimum performance of craft and artisan cooperative societies in Abia State

\begin{tabular}{|l|c|c|c|c|}
\hline \multicolumn{1}{|c|}{ Factor (s) } & Affect very greatly & Affect greatly & Do not greatly affect & Do not affect at all \\
\hline Insufficient fund & 198 & 144 & 41 & 17 \\
\hline Migration & 136 & 157 & 68 & 39 \\
\hline Lack of government support & 171 & 135 & 21 & 73 \\
\hline Corrupt leadership & 214 & 150 & 17 & 19 \\
\hline Poor welfare to members & 150 & 129 & 67 & 54 \\
\hline Lack of educated members & 13 & 73 & 91 & 223 \\
\hline
\end{tabular}

*Multiple responses

Source: Author's Fieldwork, 2013

Result in table 4 above shows that the limiting factors to the optimum performance of the group ranges from insufficient fund (342 respondent); migration (293 respondents); lack of government support (306 respondents); Corrupt leadership (usually among the executives); (364 respondents); poor welfare to members (279 respondents); and; lack of educated member (86 respondents).

\section{Conclusion}

This paper examines the role of craft and artisans cooperative societies in the advancement of its members. The paper considered cooperative societies as a form of social interaction. Exploring the exchange theory, the paper x-rayed who benefit in a social interaction. Cooperative societies have great potentials for assisting rural economy and encouraging small and medium scale enterprises (SMEs), it increases the chances of assessing fund which is seen as challenge to rural ventures. This paper has proved that the entire activities of craft and artisan cooperative societies are capable of promoting self-reliance, cooperation, improving rural economy, better the living condition of rural people especially those who are engage in one local venture or the other, and are ready to involve in cooperative initiative.

From the foregoing, organize effort to mobilize craft and artisans for cooperative spirit in the study area, and anywhere else, could assist to increase access to fund, dissemination of information and innovations, and reduce poverty. Enhancing the effectiveness of craft and artisan cooperative societies has a significant implication for community development; which according to Udensi, (2012); Udensi, et al. (2013) and Bassey, et al. (2013) have the capacity to improve the living condition of rural people, boast their economy and organize the teeming population of the youths for change and national development.

\section{References}

Aremu, M. A. (2004). Small Scale Enterprises: Panacea to poverty problem in Nigeria. Journal of enterprises development, 1(1):1-8.

Audu, S.I., Salui, O.J., and Enefola, F.O. (2007). Savings mobilization by cooperative societies in Abaji Local government Area of Kogi State, Nigeria. Patnsukjournal, 3(2):1-10.

Bassey, A. B., Udensi, L. O., Daasi, Gibson L.K., and Igbara, F. N. (2013). Engaging MOU and People's Participation in Project Implementation: Imperative for Sustainable Community Development in Nigeria. Research on Humanities and Social Sciences, 3(2): 27-31.

Berko, S. Y. (2001). Agricultural Producer Co-operatives and Agricultural development in Nigeria. Journal of Cooperative Economics and management, 1(1):54-89.

Braverman. A., Guasch, J, L., Huuppic, M., and Poulmeier, L. (1991). Promoting rural co-operative in developing countries: The case of 
Sub-Saharan Africa. World Bank discussion paper: 121. Washington, D. C.: World Bank.

Charles, J.O. (2010). Sociological Theory: A Historic - Analytical approach on Man and Society. Lagos: Serenity.

Dogarawa, A. (2005). The role of cooperative societies in economic development. MPRA paper No. 23161. Available online at: http://mpra.ub.unimuenchen.de/23161. Retrieved on: August 27, 2012.

Ebonyi, V. and Jimo, O.B. (2002). Cooperative movement: A way out of poverty. Longman publisher

Ekong, C. (2007). Sustainable saving and credit scheme in rural communities: An operational guide. Port Harcourt: Pioturu books.

Gertler, M. (2001). Rural cooperatives and sustainable development. Saskatoon SK: Center for the study of cooperatives, University of Suskatchewan.

Gibson, R. (2005). The role of cooperatives in community economic development. RID working paper \#2005-3.

ICA (1995). Statement on the cooperative Identity. ICA, Geneva. Available online at: http://www.coop.org/coop/principles.html. Retrieved on: April 4, 2009.

ILO (2001). Promotion of cooperatives. Geneva: International Labour Office. Report V: (1).

Mukarugwiza, E. (2010). The hope for rural transformation: A rejuvenating cooperative movement in Rwanda. Dares Salaam: International Labour Office.

Ndifon, H. M., Agube, E,I., and Odock, G.N. (2012). Sustainability of agricultural cooperative societies in Nigeria: the case of SouthSouth zone, Nigeria. Mediterranean Journal of social sciences, 3(2):19-25.

Ritzer, G. (2008). Sociological Theory (7th Edition). New York: McGraw-Hill.

Udensi, L. O., Daasi, Gibson L.K., Emah, D. S., and Zukbee, S. A. (2013). Youth Participation in Community Development (CD) Programmes in Cross River State: Implications for Sustainable Youth Development in Nigeria. .IOSR Journal of Humanities and Social Science (IOSR-JHSS), 13(5):61-67.

Udensi, L.O. (2012). Traditional Governance and the Challenges of Community Development: A Case Study of Boki Local Government Area of Cross River State. Unpublished M.Sc. Thesis, Department of Sociology and Anthropology, University of Uyo, Nigeria.

UWCC (2002). Cooperatives. University of Wisdom Center for Cooperative. Available online at: http://www.uwcc.com. 
